\title{
Pre-Inoculation with Bradyrhizobium spp. in Industrially Treated Soybean Seeds
}

\section{Fernanda Brunetta Godinho Anghinoni ${ }^{*}$, Alessandro Lucca Braccini ${ }^{2}$, Carlos Alberto Scapim², Guilherme Anghinoni' ${ }^{1}$ Glaucia Cristina Ferri' ${ }^{1}$, Andréia Kazumi Suzukawa', Telmo Antonio Tonin ${ }^{2}$}

\author{
${ }^{1}$ Postgraduate Program in Agronomy, State University of Maringa, Maringa, Brazil \\ ${ }^{2}$ Department of Agronomy, State University of Maringa, Maringa, Brazil \\ Email: ${ }^{\star}$ ferbrunettag@gmail.com
}

How to cite this paper: Anghinoni, F.B.G., Braccini, A.L., Scapim, C.A., Anghinoni, G., Ferri, G.C., Suzukawa, A.K. and Tonin, T.A. (2017) Pre-Inoculation with Bradyrhizobium spp. in Industrially Treated Soybean Seeds. Agricultural Sciences, 8, 582590

https://doi.org/10.4236/as.2017.87044

Received: May 1, 2017

Accepted: July 22, 2017

Published: July 25, 2017

Copyright $\odot 2017$ by authors and Scientific Research Publishing Inc. This work is licensed under the Creative Commons Attribution International License (CC BY 4.0).

http://creativecommons.org/licenses/by/4.0/

\begin{abstract}
The objective of this study was to compare the effect of anticipated and traditional inoculation of Bradyrhizobium spp. in industrially treated soybean seeds. The experiment was conducted in a randomized complete block design, with 10 treatments and 4 replications. Different combinations of insecticides and fungicides of industrial treatment of seeds, traditional inoculation and longterm (LT) inoculation, as well as different pre-inoculation periods performed at 0,5 and 10 days before soybean sowing were evaluated. A treatment containing only nitrogen mineral fertilization and also a control treatment were included. The characteristics number of nodules per plant, seeds Nitrogen content, number of pods per plant, mass of thousand seeds and grain yield were evaluated. Results indicated that LT pre-inoculation combined with fludioxonil and thiamedoxan allowed seed storage up to 10 days without affecting soybean yield components.
\end{abstract}

\section{Keywords}

Nitrogen, Nodulation, Insecticide, Fungicide, Yield

\section{Introduction}

Soybean crop established a large importance on the economic scenario for different countries, especially in the last decades [1], because of its high protein content, about 35\% - 40\%, playing an important role in human and animal nutrition [2].

Nitrogen stands out as an important nutrient, participating in the composition of amino acids, proteins, chlorophyll and many essential enzymes, stimulating roots and shoots growth. There is a high concern about $\mathrm{N}$ use in agriculture, since losses by volatilization, denitrification, erosion and leaching that 
usually results in nitrate accumulation in rivers, lakes, and water table [3]. Additionally, the high prices of these fertilizers directly affect the soybean production costs, especially when the $\mathrm{N}$ application is misused. Therefore, reducing the demands in soybean fertilization and in other crops, such as corn and wheat, may cause economic and environmental improvements in agriculture.

To produce $1 \mathrm{Mg}$ of soybean grains, the plant extracts approximately $80 \mathrm{~kg} \cdot \mathrm{ha}^{-1}$ of $\mathrm{N}$. The economic and environmental benefits of nitrogen fixation can be summarized, according to [4], as: profitability, energetic efficacy, plant nutrition and human safety, environmental quality and sustainable agriculture. The utilization of Bradyrhizobium spp. inoculation can result in an economy of US \$3 billion in each growing season [5].

Seed inoculation prior to commercialization, or even inoculation few days prior the sowing (pre-inoculation), is current practices adopted by some countries for decades, for soybeans and other crops [6] [7] [8] [9]. However several factors influence the implementation of this practice such as the bacteria ability to remain active on the seed, seed storage conditions, as well as the influence of other products added to the soybean seeds during inoculation. The association between the pre-inoculation and the industrial treatment of seeds (ITS) commonly used by seed companies, has been poorly studied and explored by the specialized literature.

This study is based on the hypothesis that the anticipated seed inoculation induces changes on biological nitrogen fixation (BNF) and soybean grain yield when compared to conventional inoculation performed at the moment of sowing. The objective of this study was to evaluate the effect of pre-inoculation and traditional inoculation of industrially treated soybean seeds on plant nodulation, nitrogen content and grain yield components of soybean, for two consecutive years.

\section{Materials and Methods}

The experiment was conducted on the summer growing seasons of 2013 and 2014, at the Iguatemi Experimental Farm of the State University of Maringá, Paraná State, Brazil (geographical coordinates $23^{\circ} 25^{\prime} \mathrm{S} ; 51^{\circ} 57^{\prime} \mathrm{O}, 540 \mathrm{~m}$ above sea level). The climate was described as subtropical humid mesothermic (Cfa) according to Köppen classification. Annual average temperature and precipitation are $22^{\circ} \mathrm{C}$ and $1450 \mathrm{~mm}$, respectively.

The combination of two industrial seeds treatment methods (ITS1 and ITS2) with four different inoculation methods, plus a mineral $\mathrm{N}$ supply and a control treatment (without $\mathrm{N}$ supply) resulted in ten treatments for the study. ITS1 consisted on seeds treating with Carbendazim and Thiram via commercial product (Derosal Plus ${ }^{\oplus}$ ) on a $2 \mathrm{~mL} \cdot \mathrm{kg}^{-1}$ seeds dose, as well as Imidacloprid and Thiodicarb via commercial product (Cropstar ${ }^{\circledR}$ ) on a of $5 \mathrm{~mL} \cdot \mathrm{kg}^{-1}$ seeds dose. ITS2 consisted on seeds treating with Fludioxonil (Maxim Advanced ${ }^{\Phi}$ ) on a $1 \mathrm{~mL} \cdot \mathrm{kg}^{-1}$ seeds dose and Thiametoxan (Cruiser $350 \mathrm{FS}^{\odot}$ ) on a $2 \mathrm{~mL} \cdot \mathrm{kg}^{-1}$ seeds dose. Each ITS1 and ITS2 received the four inoculation treatments: 1) traditional seed in- 
oculation, and 2) three pre-inoculation treatments (0, 5 and 10 days before sowing) with LT inoculant (Masterfix Premier $\left.{ }^{\circledast}\right)$. Table 1 describes all treatments cited.

The inoculants (traditional and LT) were used on the liquid form, aiming the inoculation of Bradyrhizobium elkanni (strain SEMIA 5019) and Bradyrhizobium japonicum (strain SEMIA 5079), on a concentration of $5 \times 10^{9}$ colony-forming units in each $\mathrm{mL}$.

In the first growing season, the sowing was performed in October $28^{\text {th }}, 2013$. In the second growing season the sowing was carried out in October $17^{\text {th }}, 2014$. In both growing seasons, the soil was tilled 15 days prior to sowing. The cultivar BMX Potência RR (BRASMAX Seeds) was used in the study. This cultivar belongs to the semi-early maturity group (6.7) and presents an undetermined growth habit.

Right after seeds treatment, manual sowing was carried out. Sowing rows were spaced $0.45 \mathrm{~m}$, and sowing depth was approximately $0.03 \mathrm{~m}$, with a density of 15 seeds $\mathrm{m}^{-1}$, resulting in a final stand of 12 plants per linear meter. The experimental plots consisted of five rows of $5 \mathrm{~m}$ each. The useful area consisted of the three central rows discarding $0.5 \mathrm{~m}$ of each border, resulting in $5.4 \mathrm{~m}^{2}$ used for the evaluations in this study. The same cultural practices were performed in both growing seasons.

The characteristics evaluated in both growing seasons were: number of nodules per plant (NN), seed Nitrogen content (NSE), number of pods per plant (NP), mass of thousand seeds (MTS) and grain yield.

The nodulation was evaluated when the plants were at R2 phenological stage by randomly collecting 10 plants in each plot, excluding the rows destined to yield evaluations. Each plant was collected with an undisturbed block of soil (0.4 $\mathrm{m} \times 0.4 \mathrm{~m}$ area and $0.2 \mathrm{~m}$ depth) with a cutting shovel after a constant rainfall.

Table 1. Traditional liquid inoculant and LT (long-term) liquid inoculant in treatments of soybean seeds, in 0,5 and 10 days before soybean sowing, and treatments consisting in $\mathrm{N}$ mineral fertilization and control. (Maringá-PR, 2013 and 2014 growing seasons).

\begin{tabular}{lcc}
\hline $\mathbf{N}^{\circ}$ & \multicolumn{2}{c}{ Treatments } \\
\hline $\mathbf{1}$ & Control & Without seed treatment and inoculant \\
$\mathbf{2}$ & $200 \mathrm{~kg} \cdot \mathrm{ha}^{-1}$ of N & \\
$\mathbf{3}$ & Traditional inoculant L $\left(2 \mathrm{~mL} \cdot \mathrm{kg}^{-1}\right)$ & \\
$\mathbf{4}$ & LT Inoculant $\left(2 \mathrm{~mL} \cdot \mathrm{kg}^{-1}\right)-0$ days & Industrial treatment of seeds 1 (ITS1)* \\
$\mathbf{5}$ & LT Inoculant $\left(2 \mathrm{~mL} \cdot \mathrm{kg}^{-1}\right)-5$ days & \\
$\mathbf{6}$ & LT Inoculant $\left(2 \mathrm{~mL} \cdot \mathrm{kg}^{-1}\right)-10$ days & \\
$\mathbf{7}$ & Traditional inoculant L $\left(2 \mathrm{~mL} \cdot \mathrm{kg}^{-1}\right)$ & \\
$\mathbf{8}$ & LT Inoculant $\left(2 \mathrm{~mL} \cdot \mathrm{kg}^{-1}\right)-0$ days & Industrial treatment of seeds 2 (ITS2) $)^{* *}$ \\
$\mathbf{9}$ & LT Inoculant $\left(2 \mathrm{~mL} \cdot \mathrm{kg}^{-1}\right)-5$ days & \\
$\mathbf{1 0}$ & LT Inoculant $\left(2 \mathrm{~mL} \cdot \mathrm{kg}^{-1}\right)-10$ days & \\
\hline
\end{tabular}

${ }^{*}$ Carbendazim and Thiram (Derosal Plus $\left.{ }^{\circledR}\right)\left(100 \mathrm{~mL} 50 \mathrm{~kg}^{-1}\right.$ seeds) + Imidacloprid and Thiodicarb (Crops$\left.\operatorname{tar}^{\circledast}\right)\left(250 \mathrm{~mL} 50 \mathrm{~kg}^{-1}\right.$ seeds); ${ }^{*}$ Fludioxonil (Maxim Advanced $\left.{ }^{\circledast}\right)\left(50 \mathrm{~mL} 50 \mathrm{~kg}^{-1}\right.$ seeds) + Thiametoxan (Cruiser 350FS $\left.{ }^{\circledast}\right)\left(100 \mathrm{~mL} 50 \mathrm{~kg}^{-1}\right.$ seeds). 
NN was obtained by counting the number of nodules in each plant. The NP was obtained at R7 phenological stage, by counting the number of pods in 10 plants per plot randomly collected. Yield was obtained by manually harvest plants from the useful plot area at R8 phenological stage. Mass of thousand seeds was calculated using the adjustment of seed mass and seed water content, obtained by submitting seeds to $105^{\circ} \mathrm{C}$ temperature for 24 hours. Then, MTS was adjusted to a $13 \%$ humid base mass. The Kjeldahl method was used to determine seed $\mathrm{N}$ content as recommended by [3] [4] [5] [10]-[15].

The experiment consisted in a randomized complete block design, with four replications. The data was submitted to a joint ANOVA, and the similarity of mean squares was compared by the Hartley test. The joint analysis was performed for different treatments when ratio between the lowest and the highest mean squares was lower than seven. Comparison between treatment means, when the factor was qualitative with fixed effects, was performed through orthogonal contrasts.

$\mathrm{F}$ test was used for comparisons in each contrast with $\mathrm{p}<0.05$ with the SAS/ STAT analytical package [16].

\section{Results and Discussion}

The joint analysis for NN, NSE, NP, MTS, and yield is resumed in Table 2. The comparison in contrast $\mathrm{C} 1$ indicates that all treatments submitted to seed innoculation, as well as the application of $200 \mathrm{~kg} \cdot \mathrm{ha}^{-1}$ of $\mathrm{N}$, positively influenced the measured traits, in comparison to the control. NN, yield and NP had no statistical difference according to the contrast C2 ( $p<0.05)$. Despite lack of difference, $\mathrm{N}$ fertilization performed after sowing is a questionable practice, as a result of higher costs of $\mathrm{N}$ fertilization compare to the seed inoculation [12]. Factors

Table 2. Joint analysis of orthogonal contrasts ( $F$ test) for number of nodules per plant (NN), seeds Nitrogen content (NSE), number of pods per plant (NP), mass of thousand seeds (MTS) and grain yield of soybean evaluated with different inoculation and pre-inoculation treatments of industrially treated seeds, on the 2013/2014 and 2014/2015 growing seasons.

\begin{tabular}{|c|c|c|c|c|c|c|}
\hline & \multirow{2}{*}{ Contrasts } & \multicolumn{5}{|c|}{ Contrasts estimates } \\
\hline & & $\mathrm{NN}$ & $\mathrm{NP}$ & NSE & MTS & Yield \\
\hline $\mathrm{C} 1=$ & Control vs The remaining $=$ & $-143.62^{*}$ & $-232.42^{\star}$ & $-13.87^{*}$ & $-98.53^{*}$ & $-7815.02^{*}$ \\
\hline $\mathrm{C} 2=$ & $200 \mathrm{~kg} \cdot \mathrm{ha}^{-1} \mathrm{~N}$ vs The remaining $=$ & $-97.04^{\mathrm{NS}}$ & $-62.96^{\mathrm{NS}}$ & $-8.96^{*}$ & $-21.98^{*}$ & $-2715.62^{\mathrm{NS}}$ \\
\hline $\mathrm{C} 3=$ & TIS1 vs TIS2 = & $-29.78^{*}$ & $-25.67^{*}$ & $-0.63^{*}$ & $15.18^{\mathrm{NS}}$ & $93.75^{\mathrm{NS}}$ \\
\hline $\mathrm{C} 4=$ & Tradicional (ITS1) vs LT (ITS1) = & $-4.58^{\star}$ & $-11.68^{\mathrm{NS}}$ & $-3.86^{\mathrm{NS}}$ & $13.98^{*}$ & $721.33^{*}$ \\
\hline $\mathrm{C} 5=$ & LT [0 days (ITS1) vs 5 and 10 days (ITS1)] = & $-13.87^{\mathrm{NS}}$ & $1.76^{\mathrm{NS}}$ & $-3.58^{\mathrm{NS}}$ & $0.78^{\mathrm{NS}}$ & $250.84^{\mathrm{NS}}$ \\
\hline $\mathrm{C} 6=$ & LT [ 5 days (ITS1) vs 10 days (ITS1)] = & $2.90^{*}$ & $-5.52^{\mathrm{NS}}$ & $0.10^{*}$ & $-0.12^{\mathrm{NS}}$ & $-296.50^{\mathrm{NS}}$ \\
\hline $\mathrm{C} 7=$ & Traditional (ITS2) vs LT (ITS2) = & $-27.81^{*}$ & $-19.18^{\mathrm{NS}}$ & $-4.22^{\mathrm{NS}}$ & $8.65^{\mathrm{NS}}$ & $482.41^{\mathrm{NS}}$ \\
\hline $\mathrm{C} 8=$ & LT [days (ITS2) vs 5 and 10 days (ITS2)] = & $-7.91^{*}$ & $-5.56^{\mathrm{NS}}$ & $1.83^{*}$ & $2.37^{\mathrm{NS}}$ & $-356.59^{\mathrm{NS}}$ \\
\hline $\mathrm{C} 9=$ & LT $[5$ days (ITS2) vs 10 days (ITS2) $]=$ & $17.45^{\star}$ & $18.85^{\mathrm{NS}}$ & $2.53^{\mathrm{NS}}$ & $4.34^{\mathrm{NS}}$ & $-121.24^{\mathrm{NS}}$ \\
\hline
\end{tabular}

${ }^{\star}$ Significant at $5 \%$ probability by the $\mathrm{F}$ test. ${ }^{\mathrm{NS}}$ Non significant at $5 \%$ probability by the $\mathrm{F}$ test. 
such as soil chemical, biological and mineralogic characteristics may influence leaching, volatilization, plants absorption or immobilization at the microbian mass of N. According to [17] BNF is the most sustainable N source for soybean, considering environmental and economic aspects. Depending on its efficiency, BNF may supply all $\mathrm{N}$ demanded by soybean to achieve highest yield [8]. At the Cerrado region, [17] [18] [19] found similar results to this study, for NN and NP, when the application of $200 \mathrm{~kg} \cdot \mathrm{ha}^{-1}$ of $\mathrm{N}$ (in two split applications) was compared to inoculation treatments. According to [20] the mineral $\mathrm{N}$ nutrition in soybean production reduces plant nodulation and does not lead to higher yield when compared to seed inoculation. However, in the same study, [20] also emphasize that application of mineral $\mathrm{N}$ up to $20 \mathrm{~kg} \cdot \mathrm{ha}^{-1}$ does not affect soybean yield.

The comparison in C2 (Table 2), shows that the traits NSE and MTS were statistically different, indicating that seed inoculation overcomes the effects of nitrogen fertilization, regardless the method used. This result is a response to the adverse effect of $\mathrm{N}$ fertilization on BNF, due to decrease of oxygen rates for nodules respiration [7] and to decrease on carbohydrates for nodules metabolism [13], causing a decay in nodulation. [13] reported that mineral $\mathrm{N}$ fertilization caused decreases in nitrogenase activity up to $50 \%$. That finding is a response to accumulation of nitrate and nitrite in the nodules, inhibiting the BNF by decreasing the methabolical energy availability to the bacterioids.

The contrast C3 (Table 2) indicates that the effect of ITS2 overcome the effect of ITS1 for the traits NN, NP, and NSE. In this case, the mixture of Carbendazim and Thiram may have promoted a reduction in $\mathrm{NN}$, which subsequently influenced NSE. [11] also identified that Fludioxonil + Tiametoxam did not reduce nodulation in soybean, regardless the concentration. However, [21] found that Imidacloprid and Thiodicarb, as well as Acephate and Carbofuram, reduced the physiological potential of soybean seeds. Yield and MTS were not different influenced by ITS1 and ITS2, as illustrated in C3. It is possible to infer that, despite NP being a yield component, this trait had lower influence on yield than MTS, since NP showed statistical difference between ITS1 and ITS2, and yield did not. This response may be related to the fact that other yield components influence plant yield, presenting the same behaviour of yield, such as in MTS. These results agree with [22] that reported higher protection of seeds and plantlets on field condition when Carbendazim and Thiram, Imidacloprid and Thiodicarb, as well as micronutrients and polymers were applied, with no effect on grain yield. [14] demonstrated that the use of the insecticides Fipronil, Thiametoxam and Imidacloprid on soybean seed treatment of the cultivar BMX Potência RR, did not influence the crop development.

The result obtained through contrast C4 indicates higher values for MTS and yield when seeds were submitted to standard inoculation. Moreover, the use of LT inoculant promoted higher $\mathrm{NN}$ in both growing seasons. [23] studied the influence of soybean seeds treated with different fungicides on the Bradyrhizobium survival, and found $60 \%$ of reduction on Bradyrhizobium cells when seeds were 
treated with Carbendazim and Thiram at 2 and 4 hours after inoculation. However, 48 hours after inoculation, bacteria survival was drastically decreased in all treatments, indicating that sowing operation must occur within 24 hours after inoculation. Other studies suggest that, although this fungicides present low toxicity for B. japonicum SEMIA 5079 and SEMIA 5080, the joined effect of Carboxim and Thiram is negative when inoculation is performed at sowing date [1]-[20] [22] [23] [24] [25].

All studied traits had no effect for the comparison in C5 (Table 2). This indicates that the use of LT inoculant allied to ITS1 has the same effect when performed at 0,5 or 10 days before sowing without any negative influence on soybean nodulation aspects and plant $\mathrm{N}$ supply or yield.

Nevertheless, results in C6 (Table 2) indicate that the use of LT inoculant and ITS1, highly influence NN and NSE when seeds where treated 5 days before sowing, in comparison to 10 days before sowing. [1]-[18] [20] [22] [24] reported higher NP, MTS and yield when seeds where inoculated 5 days before sowing. However, despite the fact that NN and NSE are different, yield components were not affected when inoculation was performed 10 days before sowing.

When ITS2 was used, LT inoculant caused higher NN on both growing seasons, as shown by contrast C7 (Table 2). However, the other indicators measured had no significative difference.

According to the contrast C8 (Table 2), higher NN was observed when seeds were pre-inoculated, while NSE showed high values when seeds were inoculated on the sowing date. For seeds treated with ITS2, reduction in nodulation and NSE was observed for seeds pre-inoculated 10 days before sowing, in comparison to the treatment at 5 days before sowing. Despite that, yield components and grain yield were not affected by those influences, as shown in C6 contrast.

The comparison in C9 shows that pre-inoculation of seeds submitted to ITS2 at 5 days before sowing provides higher NN (Table 2), when compared to preinoculation performed 10 days before sowing. This result also indicates that pre-inoculation 10 days before sowing may reduce intrinsic variables related to nodulation, such as NN. Yield components expressed no difference for the comparison performed in C9. Therefore, it is possible to conclude that grain yield is not affected by pre-inoculation, although pre-inoculation may influence indirect factors related to nodulation.

Data analysis revealed that LT inoculant provided higher values for NN, independently of the ITS treatment used. However, when the industrially treated seeds were pre-inoculated with LT inoculant and stored for 10 days before sowing, a significant reduction on NN occurred, which was not observed for other indicators, such as grain yield, have not decreased. When traditional inoculation and ITS1 were used at the same time, the MTS and yield were negatively affected.

\section{Conclusions}

Soybean seeds industrially treated with Fludioxonil (50 mL $50 \mathrm{~kg}^{-1}$ seeds) and Thiametoxan (100 mL $50 \mathrm{~kg}^{-1}$ seeds) can be inoculated and stored up to 10 days 
before sowing, with no adverse effects on grain yield.

The use of $\mathrm{N}$ mineral fertilization compromises MTS and NSE, but has no negative effect on soybean yield when compared to treatments that $\mathrm{N}$ was provided by inoculation. However, higher inherent costs of $\mathrm{N}$ mineral fertilization disfavor the adoption of this method, especially when seed inoculation is available for total $\mathrm{N}$ supply.

\section{References}

[1] Dan, L.G.M., Dan, H.A., Braccini, A.L.E., Albrecht, L.P., Ricci, T.T. and Piccinin, G.G. (2011) Performance of Soybean Seeds Treated with Insecticides and Subjected to Different Storage Periods. Revista Brasileira de Ciências Agrárias, 6, 215-222 http://www.agraria.pro.br/sistema/index.php?journal=agraria\&page=article\&op=vi ewArticle\&path\%5B\%5D=agraria_v6i2a939 https://doi.org/10.5039/agraria.v6i2a939

[2] Campo, R.J., Araujo, R.S. and Hungria, M. (2009) Nitrogen Fixation with the Soybean Crop in Brazil: Compatibility between Seed Treatment with Fungicides and Bradyrhizobial Inoculants. Symbiosis, 48, 154-163.

https://www.embrapa.br/soja/busca-de-publicacoes/-/publicacao/471363/nitrogen-fix ation-with-the-soybean-crop-in-brazil-compatibility-between-seed-treatment-withfungicides-and-bradyrhizobial-inoculants https://doi.org/10.1007/BF03179994

[3] Campo, R.J. and Hungria, M. (2007) The Soybean Inoculation. Embrapa-CNPSo, Londrina, 28.

[4] Conceição, G.M., Barbieri, A.P.P., Lúcio, A.D.C., Martin, T.N., Mertz, L.M., Mattioni, N.M. and Lorentz, L.H. (2014) Seedlings Performance and Yield of Soybean Submitted to Different Chemical Treatment in Seeds. Bioscience Journal, 30, 17111720 .

[5] Day, L. (2013) Proteins from Land Plants-Potential Resources for Human Nutrition and Food Security. Trends in Food Science \& Technology, 32, 25-42. http://www.sciencedirect.com/science/article/pii/S092422441300109X https://doi.org/10.1016/j.tifs.2013.05.005

[6] Deaker, R., Roughley, R.J. and Kennedy, I.R. (2004) Legume Seed Inoculation Technology-A Review. Soil Biology and Biochemistry, 36, 1275-1288. http://www.sciencedirect.com/science/article/pii/S0038071704001269 https://doi.org/10.1016/j.soilbio.2004.04.009

[7] Denison, R.F. and Harter, B.L. (1995) Nitrate Effects on Nodule Oxygen Permeability and Leghemoglobin (Nodule Oximetry and Computer Modeling). Plant Physiology, 107, 1355-1364.

https://www.ncbi.nlm.nih.gov/pmc/articles/PMC157270/ https://doi.org/10.1104/pp.107.4.1355

[8] Embrapa, S. (2004) Soybean Production Technologies: Paraná State of Brazil-2005. Embrapa Soja, Londrina.

https://www.embrapa.br/busca-de-publicacoes/-/publicacao/467676/tecnologias-deproducao-de-soja---parana-2005

[9] Herridge, D.F. (2008) Inoculation Technology for Legumes. In: Dilworth, M.J., James, E.K., Sprent, J.I. and Newton, W.E., Eds., Nitrogen-Fixing Leguminous Symbioses, Springer Netherlands, Dordrecht, 77-115. https://link.springer.com/chapter/10.1007\%2F978-1-4020-3548-7_4

[10] Hirakuri, M.H. and Lazzarotto, J.J. (2014) Soybean Agribusiness in the World and 
Brazilian Contexts. Embrapa Soja, Londrina.

https://www.embrapa.br/busca-de-publicacoes/-/publicacao/990000/o-agronegocioda-soja-nos-contextos-mundial-e-brasileiro

[11] Hungria, M., Campo, R.J. and Mendes, I. (2007) The Importance of the Biological Nitrogen Fixation Process for the Soybean Crop: An Essential Component for the Competitiveness of the Brazilian Product. Embrapa Soja, Londrina.

https://www.embrapa.br/busca-de-publicacoes/-/publicacao/468512/a-importanciado-processo-de-fixacao-biologica-do-nitrogenio-para-a-cultura-da-soja-component e-essencial-para-a-competitividade-do-produto-brasileiro

[12] Institute, S. (2004) SAS/STAT 9.1 User's Guide. SAS institute Inc., Cary, NC.

[13] AOAC International (2016) Official Methods of Analysis of AOAC International, $20 \mathrm{Ed}$.

[14] Lamas, C., Batista Filho, A., Cintra, E.R.R., De Almeida, J.E.M. and Leite, L.G. (2012) Compatibility of the Insecticides Thiametoxam and Imidacloprid with Bradyrhizobium. Capa, 18, 17-20. http://periodicos.puc-campinas.edu.br/seer/index.php/bioikos/article/view/873

[15] Lara Cabezas, W., Trivelin, P., Kondörfer, G. and Pereira, S. (2000) Nitrogen Balance of Solid and Liquid Nitrogen Sources on Side-Dressed No-Till Corn System at Triângulo Mineiro (MG). Revista Brasileira de Ciência do Solo, 24, 363-376. http://www.scielo.br/scielo.php?pid=S0100-06832000000200014\&script=sci_abstrac $\mathrm{t} \& \mathrm{t} \operatorname{lng}=\mathrm{pt}$ https://doi.org/10.1590/S0100-06832000000200014

[16] Nicolás, M.F., Hungria, M. and Arias, C.A.A. (2006) Identification of Quantitative Trait Loci Controlling Nodulation and Shoot Mass in Progenies from Two Brazilian Soybean Cultivars. Field Crops Research, 95, 355-366. http://www.sciencedirect.com/science/article/pii/S0378429005000894 https://doi.org/10.1016/j.fcr.2005.04.012

[17] Paul, E.A. (2006) Soil Microbiology, Ecology and Biochemistry. Academic Press, Cambridge, MA. http://www.sciencedirect.com/science/book/9780125468077

[18] Serraj, R., Gyamfi, J., Rupela, O. and Drevon, J. (2004) Improvement of Legume Productivity and Role of Symbiotic Nitrogen Fixation in Cropping Systems: Overcoming the Physiological and Agronomic Limitations. In: Symbiotic Nitrogen Fixation Prospects for Enhanced Applicationin Tropical Agriculture, Oxford and IBH Publishing Co. Pvt. Ltd., New Delhi, 67-97. http://oar.icrisat.org/5337/

[19] Stephens, B.D. and Neyra, C.A. (1983) Nitrate and Nitrite Reduction in Relation to Nitrogenase Activity in Soybean Nodules and Rhizobium japonicum Bacteroids. Plant Physiology, 71, 731-735.

https://www.ncbi.nlm.nih.gov/pmc/articles/PMC1066112/ https://doi.org/10.1104/pp.71.4.731

[20] Tavares, S., Castro, P.R., Ribeiro, R.V. and Aramaki, P.H. (2007) Evaluation of the Physiological Effects of Thiamethoxam in the Treatment of Soybean Seeds. Revista de Agricultura, 82, 47-54.

[21] Vitti, G. and Ferreira, A. (1997) Synthesis of Chemical Analyzes in Plant Tissue. ESALQ-Departamento de Ciência do Solo.

[22] Zilli, J., Marson, L., Campo, R., Gianluppi, V. and Hungria, M. (2006) Evaluation of Biological Nitrogen Fixation in Soybean in First Cropping Areas in the Cerrado of Roraima. Embrapa Soja-Comunicado Técnico.

https://www.embrapa.br/busca-de-publicacoes/-/publicacao/470700/avaliacao-da-fi xacao-biologica-de-nitrogenio-na-soja-em-areas-de-primeiro-cultivo-no-cerradode-roraima 
[23] Zilli, J.É., Campo, R.J. and Hungria, M. (2010) Efficacy of Bradyrhizobium Inoculation on Soybean Pre-Sowing. Capa, 45, 335-338.

https://seer.sct.embrapa.br/index.php/pab/article/view/7807

[24] Zilli, J.É., Marson, L.C., Marson, B.F., Gianluppi, V., Campo, R.J. and Hungria, M. (2008) Soybean Inoculation by Spraying Bradyrhizobium over Plants. Pesquisa Agropecuaria Brasileira, Brasília, 43, 541-544. http://www.alice.cnptia.embrapa.br/handle/doc/124228 https://doi.org/10.1590/S0100-204X2008000400014

[25] Zilli, J.É., Ribeiro, K.G., Campo, R.J. and Hungria, M. (2009) Influence of Fungicide Seed Treatment on Soybean Nodulation and Grain Yield. Revista Brasileira de Ciência do Solo, 33, 917-923.

http://www.scielo.br/scielo.php?script=sci_arttext\&pid=S0100-06832009000400016 https://doi.org/10.1590/S0100-06832009000400016

Submit or recommend next manuscript to SCIRP and we will provide best service for you:

Accepting pre-submission inquiries through Email, Facebook, LinkedIn, Twitter, etc. A wide selection of journals (inclusive of 9 subjects, more than 200 journals)

Providing 24-hour high-quality service

User-friendly online submission system

Fair and swift peer-review system

Efficient typesetting and proofreading procedure

Display of the result of downloads and visits, as well as the number of cited articles

Maximum dissemination of your research work

Submit your manuscript at: http://papersubmission.scirp.org/

Orcontact as@scirp.org 